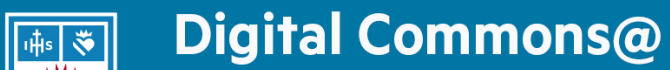

Loyola Marymount University

LMU Loyola Law School

\section{Journal of Catholic Education}

\section{The Interactional Production of Race and Religious Identity in an Urban Catholic School}

Robert Jean LeBlanc

University of Lethbridge

Follow this and additional works at: https://digitalcommons.Imu.edu/ce

Part of the Anthropological Linguistics and Sociolinguistics Commons, Curriculum and Instruction Commons, Other Education Commons, and the Race and Ethnicity Commons

\section{Recommended Citation}

LeBlanc, R. J. (2017). The Interactional Production of Race and Religious Identity in an Urban Catholic School. Journal of Catholic Education, 21 (1). http://dx.doi.org/10.15365/joce.2101052017

This Article is brought to you for free with open access by the School of Education at Digital Commons at Loyola Marymount University and Loyola Law School. It has been accepted for publication in Journal of Catholic Education by the journal's editorial board and has been published on the web by an authorized administrator of Digital Commons at Loyola Marymount University and Loyola Law School. For more information about Digital Commons, please contact digitalcommons@lmu.edu. To contact the editorial board of Journal of Catholic Education, please email JCE@nd.edu. 


\title{
The Interactional Production of Race and Religious Identity in an Urban Catholic School
}

\author{
Robert Jean LeBlanc \\ University of Lethbridge
}

This article describes how students in an urban Catholic school draw on racial and religious categories to construct classroom-specific identities during coursework. When students engage with each other in classroom discussions, they use broadly circulating, institutional, and event-level categories to position one another, and in doing so articulate who may speak and participate in class talk. This paper draws from interactional ethnographic data, showing how Vietnamese American and African American students used different religious and racial categories to delimit the interactional floor during class time and in the process exclude speakers.

\section{Keywords}

Catholic; Interaction; Classroom discussion; Linguistic anthropology; Urban

$\mathrm{B}$ roader structural changes in schools and communities have an impact on the moment-by-moment construction of classroom talk. Where Catholic schools in large urban centers such as Boston, Baltimore, and Cleveland previously could be characterized as overenrolled neighborhood parochial schools largely serving White Catholic students, today many of these same institutions are contracting and decentralized, financially compelled to move away from traditional parochial models (Jacobs, 20Io). Many of these same schools have equally transitioned to serve first- and second-generation Catholic immigrants from Asia and Latin America, alongside large numbers of non-Catholic African Americans (Louie \& Holdaway, 2009; NCEA, 20I4; Setari \& Setari, 2or6). In addition to the financial and administrative consequences of these long- and short-term transformations, these demographic and structural changes have implications in the classroom and for classroom discourse. This article considers the implications of these macro-social changes with regards to the micro-social interaction of classroom talk amongst diverse students in an urban Catholic school. Demographic changes and classroom tensions amongst Catholic school children are reflected in the construction of

Journal of Catholic Education, Vol. 2I, No. I, October 20I7, 84-IIo. This article is licensed under a Creative Commons Attribution 3.0 International License. doi: I0.15365/joce.21010520I7 
meaningful categories of differentiation by and between students, who draw on linguistic, racial, and religious ideologies to position one another. Students use classroom talk, often contentiously, to make and maintain new categories of who is in and who is out, of who is allowed to contribute to discussion and who is not. This kind of differentiating talk can have substantial implications for learning and inclusion.

Analyzing interaction among students at St. Dominic Savio ${ }^{1}$, a predominantly African American, multiethnic urban Catholic school in Philadelphia, this study illustrates how immigrant Vietnamese Catholic youth participate in the ongoing formation of racial and religious ideologies in urban Catholic schools, struggling through classroom interaction to position themselves and their non-Catholic African American counterparts. This study contributes to an emerging literature on racialized talk in contemporary urban classrooms (Reyes, 2002, 2007; Thomas, 2015) and provides insight into these practices with regards to the everyday ebb and flow of urban Catholic schools. This study further works to shed light on interactions between students in demographically- and structurally-shifting contemporary urban Catholic schools in America.

In this article, I examine a student-centered classroom discussion around a textbook focused on social justice where two eighth grade Vietnamese American Catholic students and two African American students strategically used racial and religious categories-those widely-circulating and those developed within this particular school and classroom-to socially position themselves and one another. In doing so, these students distributed speaking resources unequally based on these different categories, and turned the conversational floor into a space of contestation over who could speak and contribute based on religious and racial identities. Seeing the way these distinctions are made during classroom talk is critical in an era when urban Catholic schools seek to welcome and equitably teach a diverse range of students.

\section{Theoretical Framing}

This study draws on the traditions of New Literacy Studies and the linguistic anthropology of education (Street, 1985; Wortham, 2003) to examine classroom interactional data. Studies in these disciplines posit that learning is an inherently social action, mediated by social relationships in the classroom: who students are or are proclaimed to be has a profound effect on what kind of learning opportunities are offered to them (Bucholtz \& Hall, 2005; Wortham, 2008). These include the kinds of social categories, produced

$1 \quad$ All names are pseudonyms. 
through interaction - including categories of race and religion — which are used to classify and organize students in classrooms. I demonstrate how socially circulating categories-categories of organizing and labelling people by race, religion, schooling, and immigration status that are widely available and used outside of this particular classroom - are dynamically linked to the specific context of the interaction, including the local educational space, legacies of immigration, and the long history of Catholic schooling in America. Practically, my use of linguistic anthropology of education draws on a core concept for describing linguistic practice, indexicality (Wortham, 2003), in order to capture and frame interactional data. To understand the back and forth of classroom conversation, we must look beyond the interaction (the "speech event") in talk itself to see the distribution of socially relevant categories in historically-developed institutional orders (Heller, 1995). What comes to count as knowledge (or a contribution to knowledge) participates in social inequality through the construction of socially meaningful categories. Access to resources such as favorable identities or school-authorized language practices (including classroom level discursive resources such as identity categories) is unequally distributed through individuals positioning one another with regards to access. Students in classrooms negotiate the right to categorize and claim membership, and this negotiation is often contentious.

To contextualize micro-social interactions, I begin by considering how macro-social and meso-social phenomena contribute to ordering social relationships and as such are consequential to the ways people interact with and categorize one another. Indexicality, a term developed from sociolinguistics, illustrates the way language use carries social meaning with it which both reflects and creates context (Agha, 2003; Collins, 20I2); over time, people using language in particular ways come to represent certain models of identity. ${ }^{2}$ Bucholtz and Hall (2005) suggest that "indexicality relies heavily on ideological structures, for associations between language and identity are rooted in cultural beliefs and values" (p. 594). As such, the formation of indexical links

2 To borrow an example from Wortham and Reyes (2015), the use of a word like "dude" presupposes and creates a context where this term is appropriate, but also a kind of speaker who would use that word with frequency (likely the figure of a young man, perhaps with some geographic and temporal specificity, such as California in the early 1990s). Thus, the use of the term brings with it a range of features, contexts, and presuppositions. They further note that indexes accumulate over time in a speech event so that certain aspects of context come to be more and more relevant (including aspects such as identity). Continued use of a series of related indexicals come to presuppose a context and make it more stable. Returning to our example, many uses of the term "dude" over an interaction might establish a context which is informal (so, not a business meeting or an interaction with an elder) or caught up in young male peer discourse. All this beyond the strictly literal meaning of "dude" (a male person) insofar as language always carries social meaning with it. 
is not a neutral process. Indexes do not develop universally, as though forms of action or talk have one-to-one relationship with social characterizations, but are constructed through what Blommaert (2005) calls "orders of indexicality." Indexicals are items used in speech to call on and establish context: noting that this and not that matters in this interaction by pointing beyond themselves (indexing) to something outside. In this process, some forms of identity come to matter more and circulate further than others.

Wortham (2008) argues analysts must take into account the circulation of identity models and identity categories with regards to various timescales, not simply focusing on what we might see in interaction. At the broadest timescale level, widely circulating categories like ethnicity, social class, and race endure across decades and even centuries, and take on some stability of meaning: categories of persons persist over long timespans. At another level, people develop unique identities over a lifetime (what Wortham and others call "ontogenetic" timescales), in part by drawing together categories over weeks, months and years. Each individual comes to draw on various identity models to position themselves (and be positioned) as notable "kinds of people," which unfold over decades or a lifetime through specific events. Wortham describes this use of identity models at the mesolevel, which includes the activities and structures of classrooms (which have regular activities and structures of classroom talk which can persist for an entire academic year): over the course of a year, a student might come to be known as a "jock" or "popular" or racialized in a particular way — such as "unengaged African American boy" (more on this example below) — through multiple connected events. Finally, these broader processes which unfold over sociohistorical, ontogenetic, and meso-level timescales only exist in the moment-by-moment activities of the micro-level (the seconds, minutes, or hours of an interaction). Consequently, while we may look at micro-level interaction, our analysis must consider processes which unfold at multiple timescales.

It is here that we can see how identities within literacy events are built using multi-scaled resources, which can be re-scaled in interaction to index either locally-developed or more broadly circulating categories of identity and organization; during talk or task, students can draw on categories developed in the moment, during that week, over course of the classroom year, or more broadly in society over years or even generations. Such framing tries specifically to get away from micro-macro binaries for identity (often framed as "structure" or "agency"), and works instead toward a more nuanced set of tools for understanding identity in action. Over time, indexes cohere 
around social groups: "social indexicality," Agha (2007) demonstrates, occurs when the "contextual features indexed by speech and accompanying signs are understood as attributes of, or relationships between, social persons" ( $p$. I4). In other words, over time different ways of speaking, reading, writing, or being come to be considered key attributes of different "types" of people. For minoritized youth, this can have multiple consequences. This includes their novel engagement (against expectations) with preexisting identity categories (of race, of religion, of immigration status) in stratified spaces like schools. But equally, this includes a consideration of how those same spaces have histories of regimentation as to what identity categories are available: spaces like schools laminate identity categories, actions, and social actors over time so that social actors come to take on certain social features in certain social spaces with regularity (that is, certain actions, attributes, languages, and/or literacies get attributed to the same people over and over). This, in part, contributes to how students are racialized in schools and classrooms.

Contemporary urban Catholic schools, notably in major centers, are increasingly diverse, welcoming students from a range of racial, ethnic, and religious background (Louie \& Holdaway, 2009; NCEA, 20I4). This has, for some scholars, provoked a crisis of mission for Catholic schools, who no longer exclusively educate Catholics (cf., Baker \& Riordan, I998; Burke, 20I2; Burke \& Gilbert, 20I6). Nearly one quarter of the students currently attending Catholic schools (including urban and suburban elite) are from minority backgrounds, and 8.66\% are African American, few of whom are Catholic (Setari \& Setari, 2016). In part because of increasing Catholic suburbanization (Jacobs, 20IO), contemporary US Catholic schools are in a precarious position (Youniss \& Convey, 2000), the winds of change in the form of school choice, decreased enrolment, and increased tuition fees blowing at the walls. These days fewer and fewer students attend Catholics schools. In Philadelphia, some 80 schools have closed since the r970s, one of the most dramatic contractions in the country (MacGregor, 20I2), and in January 20I2, the Archdiocese of Philadelphia announced it was closing 48 Catholic schools, displacing some 24,000 students. Whereas Catholic schools have historically served African American students as part of broader evangelism and social justice efforts (cf., Green, 20II; Irvine \& Foster, I996), today these efforts combine with enrolment pressures, leading urban Catholic schools to heavily market themselves to local African American families, regardless of faith affiliation. This shifting context has consequences for what kind of identity models now circulate in Catholic schools, including what it means to be a "Catholic school student." 
Burke and Gilbert (2016) note that despite these changes, "research on the social experiences of students of color in private and parochial schools remains conspicuously absent" (p. 530; cf., Aldana, 20I6; Polite, 200o; Simmons, 2012 for notable exceptions). With regards to the Vietnamese students in this study, a number of contemporary studies in literacy and linguistic anthropology have highlighted the means by which Asian Americans' identities are typically framed as a "model minorities" (Lee, 200r; Ng, Lee, \& Pak, 2007) and simultaneously as "forever foreigners" (Lee, 2004, 2005). Asian Americans are positioned in educational spaces as "perpetual Others" (Reyes, 2002, 2007), inside and outside, but always "up against whiteness" insofar as Asian American students are typically positioned against the quintessentially American Black/White racial binary. This positioning is often discursively used to marginalize other minorities like African Americans and Hispanics. What it means to "be Asian American" in an institutional context is thus a matter of the distribution of identity categories, across speech chains and texts and through popular discourse.

I look particularly at the use of religious categories in Catholic schooling to further complicate Asian American identity in schools and its use to access classroom resources through discourse and framing; identity not simply "up against whiteness," but equally constructed in tandem with Catholic and non-Catholic indexicals within Catholic schools. Where scholars have examined immigrant, academic, and racial identity for Asian American students (Lei, 2003; Ng, Lee, \& Pak, 2007), produced through interaction, I am keen to explore how religious identity plays into this mix. This has particular resonance in an era of significant demographic change in urban Catholic schools, when racial identity is entangled with historical religious practice and historical religious categories. Much of this oppositional framing between racial groups, calling on model minority frames, is latent in the discourse on Asian American immigrants and as such regularly appears even in the Catholic school research literature. Zhou and Bankston (1994), in a stark example, write in their heavily-cited study on Asian American Catholic immigrants in New Orleans:

[Vietnamese Catholics] tended to cluster and rebuild their communities, mostly in declining urban neighborhoods. The residential pattern means that many Vietnamese children grow up in close proximity to urban ghettos and in the often disruptive environment of urban public schools. (p. 826) 
This kind of troublesome racial and geographic coding ("declining urban neighborhoods" and "disruptive environment of urban public schools"), including its linkage to religious categories, becomes a widely-circulating trope, used to form publically-circulating personae (Agha, 2003) which are used by students and teachers to position Asian American immigrant students in relation to their African American peers, few of whom identify as Catholic. In doing so, the students unequally claim access to the interactional floor of the classroom by invoking these institutional categories. And where others have tried to map the persistent circulation of deficit narratives more broadly in Catholic schools (Aldana, 20I6), I am particularly interested in how religious categorization functions to exclude others through interaction in the small scale back-and-forth of classroom interactions.

\section{Research Methods}

This research developed out of a larger, ongoing partnershipbetween the University of Pennsylvania and the St. Dominic Savio community (Campano, Ghiso, \& Welch, 2015; Campano, Ghiso, \& Welch, 2016; LeBlanc \& Welch, 20I6). From early October to late June-over the course of a school year-I conducted literacy- and language-focused ethnographic research in an 8th Grade class at an urban Catholic school in Philadelphia, with concentrated classroom observation and audio-recording from January to June. This typically involved me sitting in the back of class, in students' small groups, with students at Mass, or at weekly religious education (Vietnamese Eucharistic Youth Society) with a digital audio-recorder in hand, and at times recruiting them to do their own audio recordings of personal and public religious practices. I attended daily English, Religion, and Social Studies classes at the school three times a week during this period, in addition to weekly, monthly, and occasional school-based Catholic services, Mass each Sunday, and many other smaller events and moments. Altogether, data collection produced approximately ro hours of audio data each week, which were transcribed selectively using conventions typically associated with interactional ethnography (Green \& Wallat, I98r; see Appendix). These audio data were supported by daily ethnographic fieldnotes providing additional information about the context of the classroom interaction and classroom micro-culture. I further collected and electronically scanned any instructional documents, textbook pages, or religious texts used during the school day to add to my data corpus. The data analysed here draws from a larger data set (LeBlanc, 2016) to analyse a classroom interaction during a single class within this broader study. 


\section{Data Sources and Analysis}

This article analyzes a telling case (Bloome \& Carter, 20I4) of a classroom interaction in which two of the Vietnamese American boys attempted to produce racialized religious discourse in service of their Religion coursework. St. Dominic Savio is a robustly multi-cultural and multi-lingual Catholic parish. Mass is held each week in Spanish, Vietnamese, Indonesian, and English, and many community members speak Tagalog, Haitian Creole, French Creole, French, Cambodian, Mandarin, Arabic, Amharic, Tigrinya, and Tigre. While there are a number of prominent African American members of the parish, they are not a sizeable group (notably at any of the other services but those in English). The adjacent school (once parochial, now independent) is largely made up of non-Catholic African American students (some 70\%) and immigrants from Latin American and Southeast Asia.

The interaction under analysis occurred during a May 20I4 class at St. Dominic Savio. The class was divided into discussion groups of four by their teacher, Ms. Walsh, to complete an assignment drawn from the Religion textbook, Christ Our Life (2009). Prior to the start of this interaction, the class, which had been studying various aspects of Catholic social teachings on this May Day and the Celebration of St. Joseph the Worker, had just finished orally reading a two-page section of their textbook, which outlines the various teaching.

The main interactants are two Vietnamese American boys, JP and Benny, and two of their African American classmates, Gabriel ${ }^{3}$ and Charles. Both the Viet boys are Catholic and heavily involved in the liturgical life of the adjoining parish as altar servers and lectors; Gabriel is a Methodist, and regularly participates in his church, while Charles has no formal religious affiliation. Following a whole class reading of the textbook, the group was assigned by Ms. Walsh to form a small group and complete work in relation to one of the readings on the Seven Catholic Social Teachings ${ }^{4}$ : Ms. Walsh framed the next thirty minutes of class time in this way: "You are to discuss how you see

3 Gabriel identified himself in multiple ways throughout the study as "mixed", "Black" and "African American," and was equally positioned by his classmates in multiple ways. Gabriel's father identifies as "African American" and his mother as "White."These shifting racial identifiers speak to the contextual nature of racial identity in schools, but equally to the limitations of predetermined racial labeling. I have chosen to use the identifier "African American" for Gabriel in this particular transcript as he used this label himself later in the interaction, but with the acknowledgement that racial identification can pivot even within interactions.

4 Christ Our Life (2009) outlines the Seven Catholic Social Teachings as "Life and Dignity of the Human Person", "Call to Family, Community and Participation", "Rights and Responsibilities", "The Dignity of Work and the Rights of Workers", "Option for the Poor and Vulnerable", "Solidarity", and "Care for God's Creation" (p. 132). 
it [assigned Catholic Social Teaching] happening in today's world. Or what you can do to encourage it to happen in today's world." Ms. Walsh then instructed the class to form groups and discuss the contents, before leaving the room to attend to other matters in the office. After assembling their desks in a small circle at the back of the room, and placing my audio recorder in the middle, the focal group of four boys was assigned the social teaching "Option for the Poor and Vulnerable," and JP read the definition out loud before we began our discussion. ${ }^{5}$ The excerpt, which I discuss in some detail, begins as JP, Benny, Gabriel, and Charles begin to engage the assignment.

For data analysis, I looked principally to the fields of New Literacy Studies and the linguistic anthropology of education, which are concerned with "studying linguistic patterns in use, searching for the native's point of view, and trying to connect micro- and macro-level processes" (Wortham, 2003, p. 4). Because this approach is primarily discourse analytic, I originally coded across a much larger data set developed during my time at St. Dominic Savio to identify instances and literacy events of "race talk" amongst the youth. These produced a set of general codes and transcripts, which I in turn subjected to closer scrutiny using core concepts such as indexicality (Wortham, 2003) to identify language processes which implicated racial and religious categories and language use, and helped the students locally and contingently construct identity in and through interaction. To this, I look for metadiscursive talk (Collins, 20I2) wherein language and literacy practices were coded as "belonging" to particular groups or of being indexical to a particular kind of interaction. In this article, I closely examine a cluster of examples of "race talk" that overlap themes of race and Catholicism, and subjected transcripts of student talk to close scrutiny. For this study, I focus on a single interaction between the boys.

\section{Findings}

Given the unique racial and religious landscape of contemporary urban Catholic schooling (Louie \& Holdaway, 2009; Setari \& Setari, 2016), it is an ideal site to investigate the discursive production of issues around race, religion, and identity. This analysis outlines the outworking of various circulating

$5 \quad$ "Option for the Poor and Vulnerable: In our world, many people are very rich while many are extremely poor. As Catholics, to make an option for the poor means that we are called to pay special attention to the needs of those who are poor by defending and promoting their dignity and by meeting their immediate needs" (Christ Our Life, 2009, p. 133). 
discourses of anti-black racism and other forms of racial identification intersecting with more locally-developed narratives about Catholic identity in and through schooling. In doing so, I demonstrate the way religious discourse is not simply an additive category in the students' understanding of school and the space of the classroom, nor simply a resource for productively engaging with the literacy dictates of school (Juzwick, 20I4; Skerrett, 20I4), but rather undergirds a whole series of categorizations used for the social positioning. At stake in this categorization is the capacity to invoke representations of the social world, at times antagonistic and hierarchical.

\section{You're Not Part of This}

Students actively use religious and racial categories to mediate their coursework and their interactions with each other. These social interactions constitute not simply background action to a learning activity, but instead organize pathways to access the learning activity itself. Categorization came to form the grounds by which some students could or could not participate.

In some of the earliest interactions around the course text, JP and Benny worked to exclude Charles by way of racial and religious categorizations. While Charles was rarely positioned by teachers as being academically engaged, he was widely considered to be one of the most popular boys in the school. It was therefore notable to see his exclusion and the means of his exclusion in student-only talk. The boys began their class discussion by talking about potentially crafting a collage to illustrate the assigned social teaching, "Option for the Poor and Vulnerable."

$\begin{array}{lll}90 & \text { JP: } & \begin{array}{l}\text { All you gotta do is just print the pictures and put } \\ \text { them on a piece of paper }\end{array} \\ 91 & \text { Benny: } & \text { And make this stuff awesome! ((said mockingly)) } \\ 92 & \text { JP: } & \begin{array}{l}\text { (3.0) XXXXX } \\ ((J P \text { holds out my recorder, which had been sitting }\end{array} \\ 93 & & \begin{array}{l}\text { on the desk)) } \\ 94\end{array} \\ 95 & \text { Charles: } & \text { Can I can I can I see JP? } \\ 96 & \text { Charles: } & \text { Let me see it } \\ 97 & \text { JP: } & \text { You're black }\end{array}$




$\begin{array}{rll}98 & \text { JP: } & \text { You're not part of this } \\ 99 & \text { Gabriel: } & \text { ((laughs)) } \\ 100 & \text { Charles: } & \text { I got something smart to say } \\ 101 & \text { JP: } & \text { ((said like a pouting child)) I don't care } \\ 102 & & \text { ((regular voice) }) \text { You're not part of this }\end{array}$

The interaction begins immediately with the introduction of a set of racial criteria that works to exclude Charles from discussing this particularly Catholic topic; the question centers not on content, but on speaker rights. Grant and Wong (2012) remind us that asking the question "Who has the right to speak?' in classrooms enables us to understand the discursive workings of class, race, cultural and power" (p. r62), and it is crucial to use this framework to interrogate the means by which the interactional floor is opened and closed. Despite Charles' protestations that he has something to contribute to the conversation on the "Option for the Poor and Vulnerable" ("I got something smart to say"), JP speaks both personally and with authority to deny his participation ("You're black/ You're not part of this"). Of course there are a multitude of reasons to exclude a member from contributing to a small group conversation (they are talking overtop of someone else, their contribution is not relevant to the discussion at hand, they typically dominate the discussion, etc.), but this explicit exclusion based on racial identity is both troubling and strangely ironic given the framing of this discuss within issues of social justice. By invoking Charles being "black,"JP temporarily draws a boundary around the activity (with blackness seemingly out for no reason other than its color vis-a-vi racist legacies and potential local indexicality to non-Catholic religious identity) and reconfigured the classroom discussion within a limited field wherein black is out and other identities are in; that is, JP preserves the discussion of an explicitly Catholic topic not simply for those who do not fit the Catholic/non-Catholic binary (Gabriel is a Methodist), but based on racial criteria.

At my prompting, Charles eventually receives the audio recorder and begins to croon directly into it, making up lyrics about the group members as he goes along (and proving himself to be a pretty good singer: Benny acknowledges, "That's really good"). He turns his attention to JP and sings a line to him: 


$\begin{array}{lll}116 & \text { Charles: } & \text { It's Ja:aay Peee ((singing)) } \\ 117 & & \text { He is always lying } \\ 118 & \text { JP: } & \text { I never lie } \\ 119 & & \\ 120 & \text { Gabriel: } & \text { ((huge laugh)) } \quad \text { [You never lie? } \\ 121 & \text { Benny: } & \text { You never lie? } \\ 122 & \text { Gabriel: } & \text { [That's a lie right there } \\ 123 & \text { JP: } & \text { [I'm a holy person }\end{array}$

So while JP chooses to exclude Charles from the group work based on gross racial categorization (which exclude some and include other based on an indeterminate field criteria), Charles immediately uses his opportunity to turn this discussion around and frame JP, admittedly with some parody, as a "liar" (a category which negatively indexes JP's morality not only in future interactional moments, but equally in what had just come before); in doing so, Charles reauthorizes himself into the interaction. JP's retort is to invoke the identity of a "holy person" (who seemingly does not lie) as a recognizable figure of authority against the now group-wide framing of him as a "liar" (Gabriel and Benny both ask incredulously, "You never lie?").

After a good deal of what could be legitimately be coded by a teacher as "off-task" conversation, I ask how much work the group planned on doing, to which Benny replies whimsically "If it's hard we just give up." Charles, unhappy that this framing has included him (through the proximal deictic pronominal "we" that seemingly encompassed the entire group), denies this positioning:

$\begin{array}{lll}458 & \text { Charles: } & \text { I don't give up } \\ 459 & & \text { I keep trying } \\ 460 & \text { Benny: } & \text { Says the person who gonna be a lawyer } \\ 461 & \text { Gabriel: } & (\text { (laughs)) } \\ 462 & \text { Charles: } & \text { I } \underline{\text { do }} \text { wanna be a lawyer } \\ 463 & \text { Robert: } & \begin{array}{l}\text { You mentioned that once like three months ago } \\ \text { and they will not let it go }\end{array}\end{array}$


468 Benny: ((to Charles)) [I think you should be an NFL player

469 Charles: I could be the guy

470 JP: $\quad$ I destroy Charles when (0.2) when in football

471 Robert: Why [uhh why uhhh can't Charles be a lawyer?

472 Charles: [Do you wanna see my highlight tape? ((to Robert))

473 Robert: Not right now I don't

474 Charles: XXXXXX

475 Benny: ((points at Charles's arm)) You see those muscles?

$476 \quad$ They're called steroids

477 Charles They not steroids

478 They're just from lifting weights=

This excerpt requires some ethnographic framing to fully understand, as Charles' identity as an "unengaged" African American boy (a trope more broadly in the research literature and locally forged in many urban classrooms; cf. Wortham, 2005) had been formulated across multiple speech chains and events during the year, so much so that this identity had largely hardened by May 20I4 so as to undercut any classroom interactions on his part. In a previous classroom discussion, long after multiple speech events had begun to frame Charles as "unengaged" or more bluntly as "dumb," Charles mentioned he wanted to be a lawyer when he graduated, which was met with classroom laughter. ${ }^{6}$ This can be framed as an example of the scalar construction of identity in interaction, where a common circulating stereotype - the unengaged African American boy-gets produced locally and assigned to particular activities and contributions by one student-in this case, Charles. Even in group framing, however, Charles refuses this positioning and his urging that "I don't give up/I keep trying" is in specific response to Benny's claim that the group "just give up." However, this refusal does not go unremarked, and Benny counters with the retort "Says the person who gonna be a lawyer," which elicits laughter.

$6 \quad$ The Vietnamese American boys, who go to the same school and largely come from the same economic bracket as Charles, of course have their own occupational aspirations. But these middle class desires - computer technician, public worker, priest—never come under scrutiny as being unreasonable or beyond their capacity. 
Why this elicits laughter equally requires ethnographic framing (seemingly a lawyer would need to work hard and "keep going" rather than "give up" on school work). Here, we have to intuit both the tone of Benny's comment (said with a kind of ironic incredulity) and understand that the Viet boys regularly frame Charles' academic aspirations (even the most modest, like having something to contribute to a class discussion) as absurd; here, Charles' desire to be a lawyer is mocked by Benny for its overreach. This takes on another undertone when Benny pivots from Charles' aspirations to upper middle class work to frame him as a potential professional football player (and given the proximity to what came immediately before, it's hard not to see this as a move to "limit" his aspirations away from intellectual labor and towards physical labor). This equally draws on common stereotypes of African American boys as overly concerned with athletics, or that sports (typically football or basketball) are their only way "out" of urban neighborhoods (Woodbine, 2016). ${ }^{7}$ Even in this framing, the Viet boys undercut Charles' legitimacy, as his notoriety as a football star (Charles was heavily recruited to play football for a powerhouse high school in the city) is undercut by claims that he has not earned his athletic abilities: Benny claims they're the result of "steroids."

\section{What is your option for the poor?}

As the time carries on, JP, Charles, Benny, and Gabriel eventually turn to the assignment, and try to formulate some discussion about the textbook excerpt on the "Option for the Poor and Vulnerable." Benny, in a parodic repertoire that mocks my interviewing style (Benny: "I got this/I'm gonna be like you ((to Robert))/ ((turns to JP)) JP/What is your option about poor and vu:uvulnerable?"), starts the discussion and moves it back toward Ms. Walsh's original assignment frame.

567
JP: $\quad$ Well

What I think about the poor is that

They shouldn't be poor

$7 \quad$ While this might well have positive overtones-JP, for example, is a huge Philadelphia Eagles fan-Ms. Walsh's own metapragmatic framing of Charles and his African American male classmates' behavior as representing a "jock attitude" (something she comes back to both in interviews and explicitly to the class during instruction) means this indexical has a more negative undertone. Ms. Walsh explicitly comments on Charles' football abilities and links them to another racial stereotype about African American males as "criminals", commenting "Ya he might make the NFL/ He might be that good/ But he's gonna be one of those athletes that are gonna be in jail or whatever." The Vietnamese American boys' basketball skills and interest in professional sports seemingly do not garner the same framing as having a "jock attitude." 
$570 \quad$ JP: $\quad$ I think the government should do something about that

571 Charles: I know I know

572 JP: $\quad$ And when I become [the President of the United States]

573 Benny:

[What what what] should

they do to prevent that?

574 Gabriel: XXXXX

575 JP: What should I do?

576 Charles: Give everybody a million [dollars]

577 Benny: [What should] they do to prevent them from being poor?

578 Charles: Give everybody a million dollars

579 JP: $\quad$ Stop taxes

580 Charles: You need taxes

$581 \quad$ JP: $\quad$ Shut up!

582 Charles: For public schools

$583 \quad$ JP: $\quad$ I quit ((laughs))

584 Gabriel: And for all the parks and playgrounds

585 Charles: Everybody should get a million dollars

$586 \quad$ Everybody rich

587 JP: No::::::::0

588 Benny: No

589 If you get a million dollars it'll (0.2) it'll be gone in the next two days

590 Gabriel: Ya everybody spend it too fast

591 Charles: I wouldn't

592

593

$594 \quad$ JP: He got [points at Charles] he gotta hook $\mid$ strippers up and stuff

$595 \quad$ ((JP and Gabriel laugh))

596 Gabriel: He buy like 500 [pairs of shoes] 
597 Robert:

[I have] two questions then

598

599 JP:

Why do you think people are poor?

600

Because

601

They lose jobs

602

Their families left them

603

They can't

604

605

Charles: XXXXX

JP begins by narrating a fundamentally structural critique of poverty, offering an imaginative scenario (complete with an authoritative, stentorian repertoire of desk banging) of him as future President of the United States - imaginatively, Charles can't be a lawyer, but JP may be President. Charles counters with a model of extreme resource distribution ("Give everybody a million [dollars]"), to which JP counters with his own logic, which seemingly draws on discourse of a more libertarian bent: "Stop taxes." Both Charles and Gabriel interrogate this claim, and offer the necessity of taxation in America for a variety of purposes which are familiar to the participants ("For public schools," "for all the parks and playgrounds"). It is the next turn, however, that is most illuminating in terms of the interaction, as JP appears to recognize his rhetoric is not terribly compelling in this interaction ("I quit ((laughs))"), and the Viet boys turn back on Charles' suggestion of wealth distribution.

589 Benny: If you get a million dollars it'll (0.2) it'll be gone in the next two days

590 Gabriel: Ya everybody spend it too fast

591 Charles: I wouldn't

592 I'd take my time

593 Charles: I'd feel like I broke

$594 \quad$ JP: $\quad$ He got [points at Charles] he gotta hook $\mid$ strippers up and stuff

595

((JP and Gabriel laugh))

596 Gabriel: He buy like 500 [pairs of shoes] 
Whereas JP's suggestion was countered with arguments that examined the impact of his suggestion for the "public good" (drawing here on liberal discourses of necessarily public goods like schools and parks), Charles' suggestion is countered by racialized discourses of the consumerist, hypersexual African American male. Benny first accuses Charles of having little ability to prudently hold on to any money he receives ("it'll be gone in the next two days"), and where Gabriel applies the logic of "overspending" of the distributed wealth to the vague pronomial deictic "everyone" "Ya everybody spend it too fast”), JP invokes a sexualized discourse wherein he constructs an imagined scenario of Charles buying sex workers and strippers with his money. Gabriel finishes with an imagined scenario using present tense framing (as though it were going on immediately) where Charles foolishly buys huge numbers of a consumer good ("shoes") stereotypically associated with African American youth. What this all amounts to is a racialized argument against distributive economics, framed in local metapragmatic identities (Charles as "irresponsible") and broader discourses of racialized poverty wherein the poor are responsible for their own poverty because of irresponsible spending habits and moral depravity. ${ }^{8}$ Drawing on Bourdieu (Bourdieu \& Wacquant, I992), the distribution of particular categories (here, moral and racial categories) legitimize the literal distribution of economic resources and consequently demonstrate the Viet boys' use of religious identity to engage with their coursework.

Soon afterwards, we pivot in the discussion to a question I pose about Catholic (and then Christian) responsibility to care for the poor.

636 Robert: So the next question was um:::::::m

637

638

639

640

641 Benny: $\quad$ Food drive!

642 Charles: [XXXX] Why is it important for Catholic people Or Christian people to (0.4) Why like take care of the poor?

[To set] a good role model

8 Note here as well that while Charles is framed as "within" the bounds of the "poor" under discussion, JP frames the "poor' as an external Other, continually using the third person pronomial "they" in reference. This, despite the relative poverty of both students in this interaction. 


\begin{tabular}{|c|c|c|}
\hline 643 & Charles: & $\mathrm{To} /$ \\
\hline 644 & \multirow[t]{3}{*}{ JP: } & No Charles \\
\hline 645 & & You're not Christian \\
\hline 646 & & [Shut up shut up] \\
\hline 647 & \multirow[t]{2}{*}{ Charles: } & [Can I answer?] \\
\hline 648 & & I'm Christian \\
\hline 649 & \multirow[t]{5}{*}{ JP: } & No you're not \\
\hline 650 & & You're black \\
\hline 651 & & You're not Christian \\
\hline & & $\cdots$ \\
\hline 653 & & I'm Catholic \\
\hline 654 & Charles: & I'm Chris[tian] \\
\hline 655 & JP: & [You're] not Catholic \\
\hline 656 & \multirow[t]{3}{*}{ Charles: } & I’m Muslim \\
\hline 657 & & I'm Buddhist \\
\hline 658 & & I'm everything \\
\hline 659 & \multirow[t]{2}{*}{ Benny: } & How're you Buddhist? \\
\hline 660 & & $\begin{array}{l}\text { ((the other group-Kaylee, Tyler, Trina, Samara- } \\
\text { hears Charles talking and starts to laugh)) }\end{array}$ \\
\hline \multirow[t]{2}{*}{661} & Gabriel: & Charles you're a atheist \\
\hline & & $\cdots$ \\
\hline 665 & JP: & The reason we do it is to set good examples \\
\hline 666 & & As Catholics we need to represent who we really are \\
\hline 667 & & Follow Christ to help the poor \\
\hline 668 & Charles: & And $[$ cause \\
\hline 669 & JP: & [And do Jesus'work \\
\hline 670 & Benny: & Okay [I am \\
\hline 671 & Robert: & [And that's what Jesus work is? \\
\hline 672 & & Helping the poor? \\
\hline 673 & JP: & Helping the poor \\
\hline
\end{tabular}


While this starts out rather gently as a series of suggestions from Benny and JP on the subject of the question, it quickly turns to the application of a set of fused religious-racial categories to exclude Charles. When Charles tries to offer a suggestion (and given his many years of Catholic school, he no doubt has something to say), JP jumps to deny his Christianity on the basis of his race (as though the latter excluded the former) and thus exclude him from the classroom discussion:

$\begin{array}{lll}648 & \text { Charles: } & \text { I'm Christian } \\ 649 & \text { JP: } & \text { No you're not } \\ 650 & & \text { You're black } \\ 651 & & \text { You're not Christian }\end{array}$

At the most general level ("Christian" is a religious identity which can encompass many faith traditions, including variations of Protestants, Orthodox, Mormons, and, of course, Catholics), the religious identity marker is offered by $\mathrm{JP}$ as the de facto identity necessary for entrance into the discussion, and his marker is denied to Charles by virtue of being "black." This may be participating in a locally-scaled identity, as the majority of African American students at St. Dominic Savio School are not Catholic. Moving up a scale to the parish level (at least in terms of church attendance), there is a modest-sized group of African American Catholics, though none attend the Vietnamese service at which JP or Benny serve (highlighting the spatial and temporal nature of metapragmatic identity models and registers; Collins, 20I2; Stornaiuolo \& LeBlanc, 2016). Regardless, the Viet boys use a particular set of religious categorizations to exclude Charles from the conversation; Bourdieu writes helpfully about the "struggle to impose the legitimate way of perceiving the power relations... [which] can help to perpetuate or subvert these social relations" (Bourdieu \& Wacquant, I992, p. I4I), framing these kinds of social interactions as social contestations. When JP's tactic to exclude Charles based on a binary religious classification doesn't initially work and Charles continues to press his case that he is indeed "Catholic...Christian,"JP appears to concede this point, but only at the broader level (which would be "Christian").

653 Charles: I'm Catholic

$654 \quad$ I'm Chris[tian]

655 JP: [You're] not Catholic 
Bourdieu helpfully articulates religion, like any other social field, as a competitive marketplace frames this interaction as a contestation of categorizations which bring with them symbolic capital. ${ }^{9}$ At the most general level, Charles and JP struggle over the boundary marker of "Christian" and its exchangeability for offering a legitimate contribution to the classroom discussion. When Charles insists on adopting the moniker of "Christian," JP counters by refusing to grant him the legitimacy of "Catholic" (and JP's closeness to the symbolic capital of the parish, accrued over years of participation, no doubt gives him the leg up on this contestation of categorization of "Catholic") and in doing so keeps Charles at a distance by rebuffing his contributions. Denied one identity marker of religion (the "sacred capital," according to Bourdieu, associated with a formal religious group), Charles offers instead a pan-religion, cosmopolitan identity, which is met with both group- and class-wide derision:

$\begin{array}{lll}656 & \text { Charles: } & \text { I'm Muslim } \\ 657 & & \text { I'm Buddhist } \\ 658 & & \text { I'm everything } \\ 659 & \text { Benny: } & \text { How're you Buddhist? } \\ 660 & & ((\text { the other group-Kaylee, Tyler, Trina, Samara- } \\ & & \text { hears Charles talking and starts to laugh) } \\ 661 & \text { Gabriel: } & \text { Charles you're a atheist }\end{array}$

By claiming multiple religious identities as an access point to the locallyconstructed field of classroom discussion on religious matters, Charles adopts a strategy of upscaling (claiming beyond the local), which is not only battered by laughter - thus demonstrating the limitations of the fluidity of identity in interaction, notably after the emergence of an identity over the course of a school year (Wortham, 2008) - but also by the application of an identity by his classmates that would seemingly exclude him from any future discussion on the subject: "Charles you're a atheist." Thinking of identity as contextually constructed by scales and hierarchies (Stornaiuolo \& LeBlanc, 20I4, 20I6), "Catholic" appears to be the superordinate identity with the most symbolic capital in this interaction, followed by "Christian", and lastly "atheist", all of which is complicated by racial discourse. Heller (1995), after Bourdieu, calls this kind of interaction "symbolic domination," "the ability of certain groups

9 Bourdieu outlines various forms of capital beyond traditional economic capital, including cultural, social, and symbolic capital. Classification is a core part of this process, as it helps with the distribution of capital "and ensure[s] their reproduction, by adding to them the consent of the mind which they structure." (Bourdieu \& Wacquant, 1992, p. 141). 
of to maintain control over others by establishing their view of reality and their cultural practices as most valued... as the norm" (p. 373). Where Charles intends to invoke a vision of the world where one can move between hardened religious groups, the Vietnamese American boys work to place him in a distinct category (which indexes negative value in their vision of reality). In doing so, Charles' speaker rights, his ability to contribute to this conversation both in terms of content and access to the interactional floor, are foreclosed.

\section{Discussion}

There is a surprising paucity of research that has examined religious practice-Catholic or otherwise-as a resource for classroom-level talk, notably interactions around text (Juzwik, 2014; LeBlanc, 2015, 20I7). The small pockets of research that highlight this relation are largely laudatory and promotional, suggesting that "research and scholarship that pay greater theoretical and methodological attention to the religious domain of literate life" can contribute to a "more robust understanding of how literacies develop in and across interconnected social contexts, including the official world of school" (Skerrett, 20I4, p. I6). But not all literacy and classroom interactional scholars, even those with an avowedly religious perspective, have painted so comfortable a picture. Juzwik \& McKenzie (2015) introduce the reader to an evangelical student in a public school who in composing a piece for a class assignment drew on religious discourses of Biblical populism and in doing so foreclosed any openness to alternative positions or a cosmopolitan ethic; in his essay, he describes putting a "slamdown" on any "wrong views" because his own text was "authored by God." Spector (2007), in another rare example, examines a public school English classroom's engagement with the Holocaust memoir Night, and reveals that whenever students drew on religious discourse, identities, and literacies as frames for interpreting the novel, they used them not to advance statements of tolerance and acceptance, but rather to put the blame for the Holocaust on unseen malevolent forces (Satan and demons) or on the Jewish people themselves for their supposed rejection of Christ during the Passion narrative. In doing so, the students work in direct opposition to the goals teachers set in the first place for the lesson "to increase tolerance for diversity" (p. 8). Absent from this literature is a sustained discussion of the intersection of race and religious identities in language and literacy interaction. This study seeks to draw attention to the range of racial categorization available in literacy-focused classroom interaction, and its intersection with pre-existing religious categorization in service of these kinds of text-based discussions, common in any urban Catholic school. 
In the interaction under scrutiny here, when the students invoked religious rationale and identities in their completion of coursework, it was not in keeping with the explicit intent of the assignment (to take on a social justice mantel), but instead the teacher's goal was intermingled with line-byline social positioning. Here, the boys play on multiple racial and religious stereotypes, using them to shift and reposition themselves along multiple hierarchies. These stereotypes aren't just circulating cultural tropes, but rather work metapragmatically (Reyes, 2007) — they are used to do things and define things (see also Hanks, 1993). At first, we see the hierarchical positioning of Charles at the bottom of a racio-religious binary, with African Americans (as non-Catholics) at the bottom and other religious identities (first as Catholic, then as Christian) on top. While this strategy only holds for a brief amount of time, it is reconstituted later by JP, Benny, and Gabriel, who draw on stock caricatures of African American youth as spendthrift, hypersexualized, and irresponsible; and it is in forming this moral binary that we see them both completing their coursework through the use of their own religious resources, and the construction of a boundary between the deserving/undeserving poor in service of the course question "What is your option for the poor and vulnerable?" In doing so, we see their use of the coursework to jockey for position by drawing on their various distributions of capital, symbolic, cultural, and social. Together, these represent the fluid, shifting, and multi-scalar capacity of religious and racial discourse and resources in literacy practice.

\section{Conclusion}

Commenting on the racial particularity of urban neighborhoods, governmental programs, and community organizations, Wacquant (2002) describes these as "race-making institutions" which contain their own logic of racial formation that builds on and modifies broader circulating models: "They do not simply process an ethnoracial division that would somehow exist outside of and independently from them", he continues, but rather, "each produces (or co-produces) this division (anew) out of inherited demarcations and disparities of group power» (p. 54). It is on these grounds that we consider how Catholic school classrooms are "race-making institutions" which processes existing ethnoracial divisions (nationally and in the local political economy of labor competition and racism) and combine them with religious divisions and narratives through even the most seemingly mundane talk and interaction. And where a school or a classroom is equally a race-making institution which sift, sorts, and orders racial discourses and the students 
who map onto them (Lee, $2005 ; \mathrm{Ng}$, Lee, Pak, 2007), it only has meaning in relation to closely-grounded interaction, where these various contours-including the various racio-religious discourses and practices of contemporary urban Catholicism, and its engagement with contemporary immigrationare strategically and habitually recombined by students. The continuance of the Black/(Honorary)White binary offered by Lee (2005) in her study of Asian American students in schools (see also Bucholz, 2009) is complicated with a complementary discourse of religious identity and practice that equally structures interactional turns and contributes to symbolic violence. By seeing how racial and religious categories are made relevant in classrooms-how these categories are interactionally constructed, disrupted, and reformulated locally - we can see how they are mobilized by students for practices in the classroom. While explicitly social justice-oriented curriculum from the Christ our Life textbook was successful at giving students sophisticated ways of talking about structural poverty, these moments and texts were demonstrably repurposed in service of the students' own symbolic capital. For Catholic schools, in an era of significant economic and demographic change, accounting for these kinds of in-classroom differences is crucial for understanding the microproduction of difference, differentiation, and inequality.

\section{References}

Agha, A. (2003). The social life of cultural value. Language \& Communication, 23(3), 231-27I. Agha, A. (2007). Language and social relations. Cambridge, UK: CUP.

Aldana, U. (2016). Brotherhood, social justice, and persistent deficit ideologies: Latino students' experiences in an all-male Catholic high school. Journal of Catholic Education. I9(2).

Baker, D.P., \& Riordan, C. (1998). The 'eliting' of the common American Catholic school and the national education crisis. Phi Delta Kapan, 80(I), 16-23.

Blommaert, J. (1995). Discourse. New York: Cambridge University Press.

Bloome, D., \& Carter, S. P. (20I4). Microethnographic discourse analysis. In P. Albers, T. Holbrook, \& A.S. Flint (Eds.), New methods of literacy research (pp. 3-18). New York: Routledge.

Bourdieu, P., \& Wacquant, L. (1992). An invitation to reflexive sociology. Chicago, IL. University of Chicago Press.

Bucholtz, M. (2009). Styles and stereotypes: Laotian American girls' linguistic negotiation of identity. In A. Reyes \& A. Lo (Eds.), Beyond yellow English: Toward a linguistic anthropology of Asian Pacific America (pp. 21-42). Oxford, UK: OUP.

Bucholtz, M. \& Hall, K. (2005). Identity and interaction: A sociocultural linguistic approach. Discourse Studies, 7(4-5), 585-6r4. 
Burke, K. (2012). Strange bedfellows: The new neoliberalism of Catholic schooling in the United States. Journal of Pedagogy, 3(2), I77-197.

Burke, K., \& Gilbert, B.R. (20I6). Racing tradition: Catholic schooling and the maintenance of boundaries. Race, Ethnicity, and Education, $19(3), 524-545$.

Campano, G., Ghiso, M. P., \& Welch, B. (2015). Ethical and professional norms in community-based research. Harvard Educational Review, 85(I), 29-49.

Campano, H.G., Ghiso, M. \& Welch, B. (Eds.) (2016). Partnering with immigrant communities: Literacy in action. New York: Teachers College Press.

Collins, J. (20I2). Migration, sociolinguistic scale, and educational reproduction. Anthropology E' Education Quarterly, 43(2), 192-213.

Grant, R., \& Wong, S. (20I2). Critical race perspectives, Bourdieu, and language education. In J. Albright \& A. Luke (Eds.), Pierre Bourdieu and literacy research (pp. I62-I84). New York: Routledge.

Green, J.L. \& Wallat, C. (198I). Mapping instructional conversations: A sociolinguistic ethnography. In J. Green \& C. Wallat (Eds.), Ethnography and language in educational settings (pp. 161-205). Norwood, NJ: Ablex

Green, P. (20II). African Americans in urban Catholic schools: Faith, leadership and persistence in pursuit of educational opportunity. Urban Review, 43(r), 436-464.

Hanks, W.F. (1993). Metalanguage and the pragmatics of deixis. In J. Lucy, (Ed.), Reflexive language: Reported speech and metapragmatics (pp. I27-157). Cambridge, UK: CUP.

Heller, M. (1995). Language choice, social institutions, and symbolic domination. Language in Society, 24(3), 373-405.

Irvine, J. J., \& Foster, M. (Eds.). (1996). Growing up African American in Catholic schools. New York: Teachers College Press.

Jacobs, R.M. (2oro). Quaker city Catholicism: Catholic education in Philadelphia. In T.C. Hunt \& T. Walch (Eds.), Urban Catholic education: Tales of twelve American cities (pp. 27-6I). Notre Dame, IN: Alliance for Catholic Education.

Juzwik, M. (20I4). American evangelical Biblicism as literate practice: A critical review. Reading Research Quarterly, 49(3), 335-449.

Juzwik, M. M., \& McKenzie, C. (2015). Writing, religious faith, and rooted cosmopolitan dialogue: Portraits of two American evangelical men in a public school English classroom. Written Communication, 32(2), I2I-I49.

LeBlanc, R.J. (2015). Performance and apprehension of the Mass in an urban Catholic school: Strategy, liturgy, capital. Written Communication, 32(3), 254-285.

LeBlanc, R.J. (20I6). Literacy, strategy, capital: Vietnamese and Mexican immigrant students in urban Catholic schooling (Unpublished doctoral dissertation). University of Pennsylvania, Philadelphia, PA.

LeBlanc, R.J. (20I7). Interactional order, moral order: Classroom interactions and the institutional production of identities. Linguistics \& Education, 40(I), 27-37.

LeBlanc, R.J., \& Welch, B. (20I6). Cultivating civic engagement through literacy. In H.G. Campano, M. Ghiso, \& B. Welch (Eds.), Partnering with immigrant communities: Literacy in action (pp. 66-76). New York: Teachers College Press

Lee, S.J. (200I). More than 'model minorities' or 'delinquents': A look at Hmong American high school students. Harvard Educational Review, $7 r(3), 505-528$. 
Lee, S.J. (2004). Up against whiteness: Students of color in our schools. Anthropology \& Education Quarterly, 35(I), I2I-I25.

Lee, S.J. (2005). Up against whiteness: Race, school, and immigrant youth. New York: Teachers College Press.

Lei, J.L. (2003). (Un)Necessary toughness: Those 'loud black girls' and those 'quiet Asian boys'. Anthropology \& Education Quarterly, 34(2), I58-18I.

Louie, V., \& Holdaway, J. (2009). Catholic schools and immigrant students: A new generation. Teachers College Record, III(3), 783-816.

MacGregor, C.A. (2012). School's out forever: The decline of Catholic education in the United States (Unpublished doctoral dissertation). Princeton University, Princeton, NJ.

National Catholic Educational Association (NCEA) (2014). US Catholic elementary and secondary schools, 2013-20I4: Annual statistical report on schools, enrolment, and staffing. Arlington, VA: NCEA.

Ng, J.C., Lee, S.S., \& Pak, Y.K. (2007). Contesting the model minority and perpetual foreigner stereotypes: A critical review of literature on Asian Americans in education. Review of Research in Education, 3I, 95-I30.

Polite, V. (2000). Cornerstones: Catholic high schools that serve predominantly African American student populations. In J. Youniss \& J.J. Convey (Eds.), Catholic schools at the crossroads: Survival and transformation (pp. I37-156). New York: Teachers College Press.

Reyes, A. (2002). "Are you losing your culture?": Poetics, indexicality, and Asian American identity. Discourse Studies, 4(2), 183-199.

Reyes, A. (2007). Language, identity, and stereotype among Southeast Asian American youth: The Other Asian. Mahwah, NJ: Erlbaum.

Setari, P., \& Setari, R. (20I6). Trends in Catholic school minority enrollment and higher education entrance over the recession. Journal of Catholic Education, I9(3), 4-19.

Simmons III, R.W. (20I2). Exploring how African American males from an urban community navigate the interracial and intra-racial dimensions of their experiences at an urban Jesuit high school. Journal of Urban Learning, Teaching, and Research, 8(I), 4-I2.

Sisters of Notre Dame. (2009). Christ our life: The church then and now (Grade 8 Edition). Chicago, IL: Loyola Press.

Skerrett, A. (20I4). Religious literacies in a secular literacy classroom. Reading Research Quarterly, 49(2), 433-250.

Spector, K. (2007). God on the gallows: Reading the Holocaust through narratives of redemption. Research in the Teaching of English, 42(I), 7-55.

Stornaiuolo, A. \& LeBlanc, R.J. (20I4). Local literacies, global scales: The labor of global connectivity. Journal of Adolescent and Adult Literacies, 58(3), 192-196.

Stornaiuolo, A. \& LeBlanc, R.J. (2or6). Scaling as literacy activity: Mobility and educational inequality in an age of global connectivity. Research in the Teaching of English, $50(3), 263-287$.

Street, B. (1985). Literacy in theory and practice. Cambridge, UK. Cambridge University Press.

Thomas, E.E. (2015). 'We always talk about race': Navigating race talk dilemmas in the teaching of literature. Research in the Teaching of English, $50(2), 154-175$.

Wacquant, L. (2002). From slavery to mass incarceration. New Left Review, I3, 4I-60.

Woodbine, O.X.O. (2016). Black gods of the asphalt: Religion, hip hop, and street basketball. New York: Columbia University Press. 
Wortham, S. (2005). Learning identity: The joint emergence of social identification and academic learning. Cambridge, UK: CUP.

Wortham, S. (2008). Objectification of identity across events. Linguistics and Education, r9(3), 294-3II.

Wortham, S., \& Reyes, A. (2015). Discourse analysis beyond the speech event. New York: Routledge.

Wortham, S., \& Rymes, B. (Eds.). (2003). Linguistic anthropology of education. Westport, CT: Praeger.

Youniss, J \& Convey, J.J. (Eds.) (2010). Catholic schools at the crossroads: Survival and transformation. New York: Teachers College Press.

Zhou, M., \& Bankston III, C.L. (1994). Social capital and the adaptation of the second generation: The case of Vietnamese youth in New Orleans. International Migration Review, 28(4), 82I-845.

Robert Jean LeBlanc is an assistant professor of ELA/Literacy in the Faculty of Education at the University of Lethbridge (Lethbridge, AB, Canada). His research on classroom talk, Catholic schooling, and literacy has appeared in journals such as Research in the Teaching of English, Written Communication, Linguistics E Education, and the Journal of Adolescent and Adult Literacy.

Email: robert.leblanc@uleth.ca 
IIO

Journal of Catholic Education / October 2017

\section{APPENDIX}

\section{Transcription Conventions}

Adapted from Green E' Wallat, I98I

\begin{tabular}{ll}
$?$ & Rising intonation, often associated with asking a question \\
{[]} & Overlapping talk \\
\hline & Indicates a quick halt to the prose \\
$((\# . \#))$ & Ondicates a stress or emphasis \\
XXXX & Elongated letter sound \\
$(($ word $))$ & Pimed pause \\
& Portion of transcript unclear \\
& by the researcher in field notes
\end{tabular}

